BioLink, Vol. 5 (1) Agustus (2018) p-ISSN: 2356- 458X e-ISSN: 2550-1305

DOI: http://dx.doi.org/10.31289/biolink.v5i1.1663

BioLink

Jurnal Biologi Lingkungan, Industri, Kesehatan

Available online http://ojs.uma.ac.id/index.php/biolink

\title{
PEMANFAATAN TUMBUHAN OBAT DIABETES MELLITUS DI MASYARAKAT ETNIS SIMALUNGUN KABUPATEN SIMALUNGUN PROVINSI SUMATERA UTARA
}

\section{The Utilization of Diabetes Mellitus Medicinal Plants In Simalungun Ethnic Society of Simalungun Regency (North Sumatera Province, Indonesia)}

\author{
Helen Anjelina Simanjuntak* \\ Sekolah Tinggi Ilmu Kesehatan Senior Medan \\ *Corresponding author: E-mail: helenanjelinas@gmail.com
}

\begin{abstract}
Abstrak
Diabetes Mellitus merupakan masalah kesehatan yang banyak menarik perhatian karena angka prevalensi yang bertambah setiap tahunnya, terutama di negara berkembang seperti di Indonesia. Diabetes Mellitus (DM) adalah kondisi menurunnya fungsi pankreas untuk memproduksi insulin atau reseptor insulin tidak peka sehingga terjadi gangguan metabolisme dimana glukosa tidak diubah menjadi glikogen sehingga glukosa tidak dapat masuk ke dalam sel, akibatnya glukosa darah meningkat. Etnis Simalungun merupakan salah satu etnis yang terdapat di Kabupaten Simalungun Provinsi Sumatera Utara dimana masyarakat Etnis Simalungun masih memanfaatkan tumbuhtumbuhan sebagai alternatif pengobatan seperti penyakit diabetes mellitus, sehingga perlu dilakukan penelitian tentang Pemanfaatan Tumbuhan Obat Diabetes Mellitus Di Masyarakat Etnis Simalungun Kabupaten Simalungun Provinsi Sumatera Utara. Penelitian ini dilakukan dengan menggunakan metode survei eksploratif dengan variabel bebas informan. Pengumpulan data dilakukan dengan teknik wawancara secara mendalam terhadap informan yang berupa masyarakat etnis simalungun. Hasil penelitian didapatkan 26 Jenis tumbuhan, terdiri dari, 20 Famili dan 15 Ordo yang berpotensi sebagai obat antidiabetes. Bagian tumbuhan yang digunakan adalah akar, daun, buah, batang, kulit batang, biji dan umbi. Dan bagian yang paling banyak dimanfaatkan adalah daun sebanyak 40,74\%.
\end{abstract}

Kata Kunci: Simalungun, Tumbuhan Obat, Diabetes Mellitus

\begin{abstract}
Diabetes Mellitus is a health issue that attracts a lot of attention because of the prevalence rate that increases every year, especially in developing countries like in Indonesia. Diabetes Mellitus (DM) is a condition of decreasing the function of the pancreas to produce insulin or insulin receptors are not sensitive so that a metabolic disorder occurs where glucose is not converted into glycogen so that glucose can not enter the cells, resulting in increased blood glucose. Simalungun ethnic is one of the ethnic group in Simalungun Regency of North Sumatera Province where the society of Simalungun ethnic still utilize herbs as an alternative treatment like diabetes mellitus, so it is necessary to do research about the Utilization of Diabetes Mellitus Medicinal Plants In Simalungun Ethnic Society of Simalungun Regency of North Sumatera Province. This research was conducted using exploratory survey by the independent variable informant. Data collection was done by in-depth interview technique to informant. The results obtained 26 species of plants, consisting of, 20 families and 15 orders that have potential as an antidiabetic drug. Plant parts used are roots, leaves, fruit, stems, bark, seeds and tubers. And the most widely used is the leaves as much as $40.74 \%$.
\end{abstract}

Keywords: Simalungun, Medicinal Plants, Diabetes Mellitus

How to Cite: Simanjuntak, H.A. 2018, Pemanfaatan Tumbuhan Obat Diabetes Mellitus di Masyarakat Etnis Simalungun Kabupaten Simalungun Provinsi Sumatera Utara, BioLink, Vol. 5 (1): Hal. 59-71 
BioLink, Vol. 5 (1) (2018): hal. 59-71

\section{PENDAHULUAN}

Diabetes

Mellitus

merupakan

masalah kesehatan yang banyak menarik perhatian karena angka prevalensi yang bertambah setiap tahunnya, terutama di negara berkembang seperti di Indonesia (Setiawan, 2007). Diabetes Mellitus (DM) adalah kondisi menurunnya fungsi pankreas untuk memproduksi insulin atau reseptor insulin tidak peka sehingga terjadi gangguan metabolisme dimana glukosa tidak diubah menjadi glikogen sehingga glukosa tidak dapat masuk ke dalam sel, akibatnya glukosa darah meningkat. Gejala yang dapat ditemukan pada penderita diabetes melitus berupa keluhan seperti poliuria, polidipsia, polifagia, penurunan berat badan secara drastis, lemah badan, dan mata kabur (Setiawan, et al. 2011).

Menurut data WHO, Indonesia menempati urutan ke-4 terbesar dalam jumlah penderita diabetes mellitus di dunia dan pada tahun 2000 lalu diperkirakan terdapat 4 juta penderita diabetes mellitus di Indonesia. Jumlah ini diperkirakan akan terus meningkat. Pada tahun 2010 diperkirakan menjadi 5 juta dan tahun 2030 diperkirakan sekitar 21,3 juta penduduk Indonesia menderita diabetes mellitus (Dinasari, 2015).

Terapi Diabetes Mellitus (DM) yang paling utama adalah makanan dengan mengatur pola makan penderita bekerjasama dengan ahli gizi untuk menentukan makanan apa yang dapat dikonsumsi. Obat-obatan dapat diberikan apabila terapi makanan tidak berhasil. Dewasa ini masyarakat banyak lebih memilih pengobatan dengan menggunakan tanaman obat dibandingkan dengan obat-obat kimia. Salah satu penyebabnya adalah karena tanaman obat memiliki banyak keutungan, selain mudah didapatkan, mudah ditanam, dapat diramu sendiri serta murah (Zega et al, 2016).

Masyarakat Etnis Simalungun merupakan salah satu etnis yang masih memanfaatkan tumbuh-tumbuhan sebagai Obat Tradisional dalam berbagai penyakit. Obat Tradisional dari bahan alam menjadi salah satu alternatif pengobatan seperti diabetes mellitus. Penggunaan bahan alam, baik sebagai obat maupun tujuan lain cenderung meningkat terlebih dengan adanya isu back to nature (Dianasari, 2015). Lebih dari 400 jenis tanaman telah terbukti mempunyai aktivitas hipoglikemia karena dalam tanaman tersebut terkandung senyawa-senyawa yang berkhasiat sebagai antidiabetes seperti polisakarida, protein, flavonoid, alkaloid, steroid, dan terpenoid (Kim, et al., 2006). Sehingga perlu dilakukan penelitian Pemanfaatan Tumbuhan Obat Diabetes Mellitus Di Masyarakat Etnis Simalungun Kabupaten Simalungun Provinsi Sumatera Utara. 
Helen Anjelina Simanjuntak, Pemanfaatan Tumbuhan Obat Diabetes Mellitus di Masyarakat

METODE PENELITIAN

Penelitian dilakukan dengan menggunakan metode survei eksploratif dengan variabel bebas informan/battra (Pengobat tradisonal). Lima Kecamatan terpilih seperti Silimakuta, Purba, Panei, Pematang Sidamanik dan Dolok Batu Nanggar. Dari setiap kecamatan masingmasing diwakili oleh satu informan/battra (pengobat tradisional). Pengumpulan data dilakukan dengan teknik wawancara secara mendalam terhadap informan/Battra (pengobat tradisional) mengenai nama lokal tumbuhan, bagian tumbuhan yang diambil serta cara meramunya. Observasi lapangan seperti identifikasi tumbuhan, habitatnya, keadaan demografi, dokumentasi foto dan pengambilan sampel spesimen. Spesimen tanaman obat diambil untuk deskripsi morfologi, pengawetan dan pembuatan herbarium. Deskripsi morfologi dilakukan dengan mencatat bagian penting morfologi seperti: perawakan, akar, daun, batang dan bunga. Pengawetan dilakukan dengan spiritus untuk pengawetan basah, sedangkan pengawetan kering dilakukan di herbarium.

\section{HASIL DAN PEMBAHASAN}

\section{Demografi Informan}

Hasil pemetaan informan/Battra (Pengobat tradisional) Etnis Simalungun yang terdapat di wilayah Kabupaten
Simalungun berhasil diwawancarai 5 orang sebagai informan/Batrra (pengobat tradisional) yang paling terkenal, paling banyak pasiennya dan paling ampuh dalam pengobatan.

Keanekaragaman Jenis Tumbuhan Obat Berpotensi Sebagai Obat Diabetes Mellitus

Penggunaan tumbuhan obat sebagai obat diabetes mellitus terdiri dari 26 Jenis Tumbuhan, terdiri dari 15 Ordo dan 20 Famili (Tabel 1). 
BioLink, Vol. 5 (1) (2018): hal. 59-71

Tabel 1. Klasifikasi Tumbuhan Obat Berpotensi Sebagai Obat Diabetes Mellitus

\begin{tabular}{|c|c|c|c|c|c|c|c|}
\hline Dirisio & Sub Dirisio & Kelas & Sub Kelas & Ordo & Family & Genus & Spesies \\
\hline \multirow{21}{*}{ Spermatophyta } & \multirow{21}{*}{ Anģospermae } & \multirow{19}{*}{ Dicotyledoneae } & \multirow{3}{*}{ Monochlamydae } & Euphorbitiales & Euphortbiacease & Phyllanthus & 1.Phyllanthus nivuri \\
\hline & & & & Urticales & Moracene & & 2. Ficul septica \\
\hline & & & & & & Morus & 3. Morus alba \\
\hline & & & \multirow{8}{*}{ Sympetalae } & \multirow{2}{*}{ Apocynales } & Apocynacease & $\begin{array}{l}\text { Alstonia } \\
\text { Cathyrantis }\end{array}$ & 4. Alstonia scholaris \\
\hline & & & & & Loganeaceze & Strychnos & 6. Strychnos ligustina \\
\hline & & & & Asterales & Asteraceae & Traxacum & 7. Truracacun officinale \\
\hline & & & & Cucurbitales & Cucurbitaceae & Momodica & 8. Momordicacharantia \\
\hline & & & & Rubiales & Rubiaceae & Morinda & 9. Morindacitififlia \\
\hline & & & & Solmalon & I mingon & Coleus & 11. Coleus scutellaritioides \\
\hline & & & & & Lambaract & Orthosiphon & 12. Orhosiponstamineus \\
\hline & & & & menten & Solamacease & Physalis & 13. Phinsalis minima \\
\hline & & & \multirow{8}{*}{ Dialypetalae } & $\begin{array}{l}\text { Apiales } \\
\text { Geranizes }\end{array}$ & $\begin{array}{l}\text { Aptaceae } \\
\text { Oxalidprene }\end{array}$ & $\begin{array}{l}\text { Centella } \\
\text { Averthos }\end{array}$ & 14. Centella asiatica \\
\hline & & & & Malvales & Sterculiaceze & Theobroma & 16. Theobromacacao \\
\hline & & & & & & Psidium & 17.Psidiun guajara \\
\hline & & & & Mytales & Mytaceae & Syzygum & 18. Syaygium pohyanthum \\
\hline & & & & Parietales & Carricacese & Carica & $\begin{array}{l}\text { 19. Jyaggun cownon } \\
\text { 20. Carica papona }\end{array}$ \\
\hline & & & & Donle & Lauraceae & Persea & 21. Persea americana \\
\hline & & & & & Menispermeaceae & Timospora & 23. Tmosporacrispa \\
\hline & & & & Rosales & Papilionaceae & Phaseolus & 24. Phaseolus vulgaris \\
\hline & & \multirow{2}{*}{\multicolumn{2}{|c|}{ Monocotyledonear }} & Liliales & Amaryllidaceze & Allinm & 25. Alliwn cepa \\
\hline & & & & & Liliaceas & Aloe & 26. Aloevera \\
\hline
\end{tabular}

Dari Tabel di atas dapat dilihat bahwa terdapat 26 Jenis tumbuhan, 20 Famili dan 15 Ordo yang berpotensi sebagai Obat diabetes mellitus.

Phyllanthus niruri (Rumput dukung anak) merupakan jenis tumbuhan liar yang tumbuh pada tempat lembab dan berbatu. Dapat dijumpai di daerah dataran rendah sampai pada ketinggian $1000 \mathrm{~m}$ dpl. Terna, semusim, tumbuh tegak, tinggi 30-50 cm, bercabang-cabang. Kandungan kimia yang terdapat pada tumbuhan ini adalah adanya flavonoid yang terdiri dari quercetin, isoquercetrin, astragalin yang berperan sebagai obat diabetes (Dalimartha, 2000).
Ficus septica merupakan jenis perdu atau pohon kecil, tinggi antara $100-150$ $\mathrm{cm}$. Kulit batang berwarna abu-abu putih. Buah semu di ketiak daun yang luruh, bentuk buah membulat gepeng, warna buah hijau muda atau hijau keabu-abuan. Habitat hutan primer, hutan sekunder dan semak belukar. Kandungan kimia yang terdapat pada daun, buah, dan akar adalah saponin dan flavonoid, disamping itu buahnya mengandung alkaloid dan tanin, sedangkan akarnya mengandung senyawa fenol (Harada et al., 2006).

Morus alba merupakan tumbuhan berhabitus pohon yang dapat mencapai sekitar $9 \mathrm{~m}$. Batang berkayu, bulat, masih 
Helen Anjelina Simanjuntak, Pemanfaatan Tumbuhan Obat Diabetes Mellitus di Masyarakat

muda berwarna ungu setelah itu tua coklat.

Helaian daun tunggal, letak berseling, helaian daun berbeda pada daun muda dan daun tua (anisofili). Bunga majemuk, bentuk setandan, kelopak segitiga, benang sari dan putik kecil, putih mahkota bentuk tajuk, kecil, putih. Buah ketika masih muda berwarna hijau setelah tua berwarna merah, jingga atau hitam. Biji kecil, warna hitam, akar tunggang, warna putih kekuningan. Kandungan kimia berupa vitamin, asam fumarat, dan asam folat (BPOM RI, 2010).

Alstonia scholaris merupakan tumbuhan berupa pohon dengan tinggi 45 m. Perbungaan berupa malai rata, di ujung cabang atau ketiak daun, panjang sampai $13 \mathrm{~cm}$, gagang bunga pendek $\pm 2,5 \mathrm{~cm}$, berambut. Bunganya wangi, warna hijau terang sampai putih kekuningan dan pada kedua permukaannya berbulu halus dan rapat,panjang tabung 7-9 $\mathrm{mm}$, agak mengecil pada bagian lehernya, helaian mahkota mnyerong dan bundar. Panjang tangkai putik 3-5 cm. Buah bumbung panjang 20 - $50 \mathrm{~cm}$, biji-biji berambut pada bagian tepinya dan beijambul pada bagian ujungnya, panjang 1,5 - $2 \mathrm{~cm}$. Kandungan kimia pada kulit kayu mengandung alkaloida ditanin, ekitamin (ditamin), ekitenin, ekitamidin, alstonin, ekiserin, ekitin, ekitein, porfirin, dan triterpen (alfa-amyrin dan lupeol). Daun mengandung pikrinin. Bunga pulai mengandung asam ursolat dan lupeol (BPOM, 2007).

Catharanthus roseus merupakan tumbuhan berhabitus terna menahun, tumbuh tegak, bercabang banyak, tinggi mencapai $120 \mathrm{~cm}$. Batangnya berkayu pada bagian pangkal, sering bergetah putih, bentuk batang bulat. Helaian daun tunggal, terletak berhadapan dengan pertulangan daun menyirip, bentuk helaian daun memanjang, bulat telur terbalik sampai oval, pangkal runcing, ujung runcing, tepi daun rata, ibu tulang daun agak tebal dan berdaging, pertulangan daun sedikit melengkung, warna hijau, tangkai daun 5-6 mm, ukuran helaian daun 2-9 $\mathrm{cm}$, berbulu pada kedua permukaannya. Perbungaan berupa bunga majemuk menggarpu, di ketiak daun yang biasanya dipadati oleh beberapa pasang daun, panjang ibu tangkai bunga 1-2 mm, tegak. Kandungan kimianya yang berkhasiat menurunkan kadar glukosa darah (hipoglikemik) antara lain leurosin, katarantin, lochnerin, tetrahidroalstonin, vindolin dan vindolinin (BPOM RI, 2010).

Strychnos ligustrina merupakan merupakan tumbuhan semak, tinggi lebih kurang 2 meter. Berbatang kecil, berkayu keras dan kuat Bagian yang digunakan kayu dan biji. Kandungan kimia berupa mengandung alkaloid (striknin dan brusin), tanin, steroid/triterpenoid 
(saponin) sebagai penurun kadar gula darah (Gusmailina \& Sri, 2015)

Taraxacum officinale merupakan berhabitus herba menahun, tidak memiliki batang, tinggi mencapai 30-50 cm. Akar terletak dibawah tanah, berbentuk panjang, lurus, meruncing, dan berwarna cokelat, serta dapat menembus ke permukaan, tunggal ataupun sebagai cabang dari rimpangnya. Dari rimpang, tumbuh daun berbentuk roset berwarna hijau, dari tengah roset akan tumbuh bunga berwarna jingga kuning berbentuk ligulat. Buahnya berbentuk fusi, berwarna hijau hingga kecoklatan, berakhir pada tangkai kecil yang dikelilingi oleh papus lembut dan ditunjang oleh kepala buah berbentuk globular. Kandungan kimia berupa flavonoids (isoquerin, hyperin), taraxasterol, taraxacerin, taraxerol, taraxin, kolin, inulin, pektin, koumesterol, asparagine, dan vitamin (A, B, dan D) (Azhari, 2016).

Momordica charantia merupakan Tanaman berupa semak menjalar, dengan buah tipe peppo, memanjang, berjerawat tidak beraturan, oranye, pecah sama sekali dengan 3 katup, 5-7 cm (liar) hingga $30 \mathrm{~cm}$ (ditanam). Kandungan kimia berupa flavonoid, polifenol dan saponin (Yuda et al., 2013).

Morinda citrifolia merupakan Tanaman berupa pohon, buah bongkol (kepala) bersifat apokarp, berbenjol- benjol tidak teratur, jika masak berdaging dan berair, kuning kotor atau putih kuning, panjang $5-10 \mathrm{~cm}$, intinya keras seperti tulang, coklat merah, bentuk kerucut, tangkai buah 3-5 cm. Kandungan kimia berupa Mondon, skopoletin, alkaloid xeronim (BPOM RI, 2013).

Strobilanthes crispus merupakan tumbuhan berhabitus terna semusim, tegak, tinggi 0,5-1 m. Daun berhadapan, bertangkai pendek, helai daun berbentuk lanset melonjong atau hampir jorong, pinggir daun bergerigi, panjang helai daun 9-18 cm, lebar helai daun 3-8 cm, kedua permukaannya kasar. Perbungaan tersusun dalam bulir padat, gagang bunga lebih panjang dari kelopak, kelopak tertutup dengan rambut-rambut pendek, mahkota berbentuk corong, terbagi 5, panjang 1,5 - $2 \mathrm{~cm}$, berambut, berwarna kuning, benang sari 4. Buah berbentuk gelendong, mengandung 2-4 biji. Kandungan kimia berupa asam asetat, asitosterol, amonium asetat, aromadendren oksida, benzemetanol, a-(i-aminoetil)fenol, butirolakton, kampesterol, siklobutanol, asam siklopentaundekanoat, dan vitamin E (BPOM RI, 2010).

Coleus scutellarrioides merupakan terna setahun, tumbuh tegak atau berbaring pada pangkalnya, bagian yang menyentuh tanah mengeluarkan akar, tinggi 0,5-1,5 m, jika selurh bagian diremas akan mengeluarkan bau harum. 
Helen Anjelina Simanjuntak, Pemanfaatan Tumbuhan Obat Diabetes Mellitus di Masyarakat

Daun tunggal, panjang tangkai $3-4 \mathrm{~cm}$. ceplukan ini berbentuk bulat telur Helaian daun berbentuk bulat telur, memanjang (langset) dengan ujung pangkal membulat atau melekuk runcingdengan panjang 5 $-15 \mathrm{~cm}$ helaian menyerupai bentuk jantung, ujung daun tipis, kaku dan cepat layu setelah meruncing, tepi beringgit, tulang daun dipetik. Kandungan kimia berupa Fisalin B, menyirip jelas (berupa alur) berbentuk Fisalin D, dan Fisalin F (BPOM, 2007). seperti jala. Bunga dalam anak payung Centella asiatica merupakan yang berhadapan. Kandungan kimia tumbuhan terna, menahun dan stolonberupa daun dan batang mengandung stolon merayap, panjang 10-80 cm, akar minyak atsiri, fenol, tanin, lemak, keluar dari setiap buku-buku, banyak phytsterol, kalsium oksalat, dan peptic percabangan yang membentuk tumbuhan substances (Dalimartha, 2000).

Orthosiphon stamineus merupakan baru. Daun tunggal bertangkai panjang, tersusun dalam roset akar yang terdiri tumbuhan Habitus berupa terna berkayu, pada pangkal sering bercabang, disana berakar kuat; tinggi 0,4-1,5 m; Batang berambut pendek. Tangkai daun 0,4-3 cm; helaian daun bulat telur, ellips atau memanjang, dengan pangkal berbentuk baji, di atas pangkal yang bertepi rata bergigi kasar, dapat dikatakan gundul, 210 x 1-5 cm. Karangan semu banyak, terpisah, berbunga 6 , terkumpul menjadi tandan ujung. Daun pelindung kecil. Kandungan kimia berupa flavonoid hirtakoumaroflavonosida dan hirtaflavonosida B dan metoksi flavonoid dimetosikuersetrin (Sheliya et al. 2015).

Physalis minima merupakan tumbuhan semusin, batangnya tegak, tinggi dapat mencapai 1 meter, batang yang tua berkayu dan bulat, berongga berwarna hijau, percabangan muncul di ketiak daun ketiga dekat tanah. Daun dari 2-10 helai daun. Kandungan kimia berupa asiaticoside, thankuniside, iso thankuniside, madecassoside, brahmoside, brahmic acid, madasiatic acid, hydrocotyline, mesoinositol, centellose, carotenoids, garam mineral, zat pahit vellarine, dan zat samak (Dalimartha, 2000).

Averrhoa carambola merupakan tumbuhan berupa Pohon, tingginya sampai $12 \mathrm{~m}$. Percabangan banyak, arahnya agak mendatar sehingga pohon ini rindang. Daun majemuk, menyirip, bulat telur, ujung runcing, pangkal membulat, tepi rata, permukaan mengkilat di bagian atas dan permukaan bawah buram dengan bulu yang menyebar. Buah berusuk lima, bila dipotong melintang berbentuk bintang, panjang $4 \mathrm{~cm}$ sampai $12,5 \mathrm{~cm}$. rasa buah manis sampai asam. Biji putih kotor kecoklatan, gepeng, bentuk 
BioLink, Vol. 5 (1) (2018): hal. 59-71

elips dengan kedua ujung lancip. Masa berbunga sepanjang tahun. Kandungan kimia berupa ascorbic-acid, copper, fiber, magnesium, manganese, zinc, arginine (BPOM, 2007).

Theobroma cacao merupakan tumbuhan Pohon semidesidus (jarang berganti daun). Tinggi pohon mencapai rata-rata 5-10 m. Batang pohon utama pendek; cabang memutar 5, dimorfik; cabang vertikal tumbuh pada batang memiliki daun yang tersusun dalam 5/8 filotaksi. Cabang lateral memiliki Vi filotaksi. Petiola dengan 2 pulvini, satu pada dasar dan yang lain pada titik insersi daun. Stipula 2, desidus. Lamina elipslonjong atau bulat-lonjong, sederhana, panjang 10-45 cm; biasanya halus, kadang berambut, membulat pada dasar. Kandungan kimia berupa senyawa fenolat tanin; alkaloid purin: theobromin sebagai alkaloid utama, kafein dalam jumlah kecil; lemak: asam lemak oleat, asam stearat, asam palmitat; substansi proteat; tepung; monosakarida/oligosakarida: sakarosa, glukosa, fruktosa; amina biogenik: feniletilamin, tiramin, triptamin, serotonin; alkaloida isokuinolin: salsolinol; tanin katekin: oligomerik proantosianidin; dan oksalat (BPOM, 2007).

Psidium guajava merupakan tumbuhan Semak atau pohon, tinggi 3-10 m, kulit batang halus permukaannya, berwarna coklat dan mudah mengelupas. Daun berhadapan, bertulang menyirip, berbintik, berbentuk bundar telur agak menjorong atau agak bundar sampai meruncing, panjang helai daun 6-14 cm, lebar 3-6 cm, panjang tangkai 3-7 $\mathrm{mm}$, daun yang muda berambut, daun yang tua permukaan atasnya menjadi licin. Perbungaan terdiri dari 1-3 bunga, panjang gagang perbungaan 2-4 cm; panjang kelopak 7-10 $\mathrm{mm}$; tajuk berbentuk bulat telur sungsang, panjang 1,5 - $2 \mathrm{~cm}$. Kandungan kimia: pada daun selain tanin, seperti minyak atsiri, asam ursolat, asam psidiolat, asam kratagolat, asam oleanolat, asam guajaverin dan vitamin. Buah jambu biji mengandung glikosida benzofenon (BPOM RI, 2010).

Syzygium polyanthum merupakan tumbuhan Pohon, bertajuk rimbun, tinggi sampai $25 \mathrm{~m}$. daun tunggal, bila diremas berbau harum, bertangkai pendek, panjang tungkai daun $5 \mathrm{~mm}-10 \mathrm{~mm}$. helai daun berbentuk jorong memanjang, panjang $7 \mathrm{~cm}-15 \mathrm{~cm}$, lebar $5 \mathrm{~cm}-10 \mathrm{~cm}$. Ujung dan pangkal daun meruncing, tepi rata. Permukaan atas berwarna cokelat kehijauan, licin, mengkilat. Permukaan bawah berwarna coklat tua. Tulang daun menyirip dan menonjol pada permukaan bawah. Tulang cabang halus. Perbungaan berupa malai, keluar dari ranting, berbau harum. Kelopak bunga berbentuk cangkir yang lebar dengan ukuran lebih kurang 1 
Helen Anjelina Simanjuntak, Pemanfaatan Tumbuhan Obat Diabetes Mellitus di Masyarakat

mm. Mahkota bunga berwarna putih, panjang 2,5 mm-3,5 mm. Benang sari terbagi dalam 4 kelompok, panjang lebih kurang $3 \mathrm{~mm}$, berwarna kuning lembayung. Kandungan kimia berupa minyak atsiri, tannin, flavonoid (BPOM RI, 2013).

Syzygium cumini merupakan tumbuhan berupa pohon tinggi 10-20 m berbatang tebal, tumbuhnya bengkok, dan bercabang banyak. Daun tunggal, tebal, tangkai daun 1-3,5 cm. Helaian daun lebar bulat memanjang atau bulat telur terbalik, pangkal lebar berbentuk baji, tepi rata, pertulangan menyirip, permukaan atas mengkilap, panjang 7-16 cm, lebar 5-9 cm, warnanya hijau. Bunga majemuk bentuk malai dengan cabang yang beijauhan, bunga duduk, tumbuh di ketiak daun dan di ujung percabangan, kelopak bentuk lonceng berwarna hijau muda, mahkota bentuk bulat telur, benang sari banyak, berwarna putih, dan baunya harum. Buahnya buah buni, lonjong, panjang 2-3 $\mathrm{cm}$, masih muda hijau, setelah masak warnanya merah tua keunguan. Kandungan kimia berupa minyak lemak (3-5\%): mengandung asam oleat, asam miristat, asam palmitat, asam linoleat, asam sterculiat dan asam malvalat Tanin (16\%): termasuk corilagin, 3,3 '-Di-Omethyl ellagic acid, galloyl glucose (BPOM RI, 2007).
Carica papaya merupakan Tumbuhan berhabitus terna seperti pohon dengan tinggi 8-10 m. Akar tanaman pepaya tidak mengayu, oleh karena itu tanaman ini membutuhkan tanah yang gembur dengan air yang cukup pada musim kemarau dan sedikit air pada musim hujan. Batang tumbuh lurus ke atas dan tidak bercabang. Berbatang basah dengan bentuk silindrik. Kandungan kimia pada biji pepaya diantaranya protein, serat, minyak lemak, karpain, bensilisotiosianat, bensilglukosinolat, glukotropakolin, bensiltiourea, hentriakontan, B-sitosterol, karisin, dan enzim mirosin (BPOM RI, 2013).

Persea americana merupakan tumbuhan berupa pohon tinggi $3-10 \mathrm{~m}$ dengan daun tersebar, tunggal, berdesakan di ujung ranting, helaian daun berbentuk bulat telur, elips, bulat memanjang, bulat telur terbalik, menjangat, kedua sisi permukaan mulamula berambut kemudian gundul, ukuran panjang $10-20 \mathrm{~cm}$, lebar $3-10 \mathrm{~cm}$, panjang tangkai $1,5-5 \mathrm{~cm}$. Biji alpukat satu berbentuk bola, garis tengah $2,5 \mathrm{~cm}$ sampai $5 \mathrm{~cm}$. Kandungan kimia berupa Asam lemak, asam oleat, asam palmitat, asam linoleat, asam palmitoleat (tokoferol, vitamin E) (BPOM RI, 2007).

Cinnamomum burmanni merupakan tumbuhan Tumbuhan berhabitus pohon dapat mencapai $15 \mathrm{~m}$, pepagan (kulit 
BioLink, Vol. 5 (1) (2018): hal. 59-71

batang) berbau khas. Helaian daun berbentuk lonjong, panjang 4-14 cm, lebar 1,5-6 cm, permukaan atas halus, permukaan bawah berambut berwarna kelabu kehijauan yang tertekan pada permukaan daun atau bertepung, daun muda berwarna merah pucat; berpenulangan 3; panjang tangkai daun 0,5-1,5 cm. Perbungaan berupa malai, berambut halus, berwarna kelabu yang tertekan pada permukaan; panjang tangkai bunga 4-12 mm, juga berambut halus; tenda bunga panjang 4- $5 \mathrm{~mm}$, helai tenda bunga sesudah berkembang tersobek secara menyilang dan terpotong agak jauh dari dasar bunga; benangsari mempunyai kelenjar ditengah-tengah tangkai sari. Buah adalah buah buni panjang $\pm 1 \mathrm{~cm}$. Kandungan kimia berupa minyak atsiri 1-3\% dengan kandungan kimia utama kulit kayu manis adalah sinamaldehid $(60-85 \%$ dari komponen minyak atsiri), tanin, damar, lendir, kalsium oksalat (BPOM RI, 2010).

Tinospora crispa merupakan tumbuhan merambat atau memanjat, tinggi batang dapat mencapai 2,5 meter, yang memiliki batang berwarna hijau penuh dengan benjolan yang rapat, pegangannya mudah terkelupas. Kandungan kimia terdiri dari Alkaloid berberin dan kolumbin, glikosida pikroretosida, zat pahit pikroretin, damar lunak dan palmitin (BPOM RI, 2013).

Phaseolus vulgaris merupakan Tumbuhan berhabitus semak setahun, termasuk jenis tanaman kacangkacangan dengan batang tumbuh membelit, berambut halus, panjang mencapai $3 \mathrm{~m}$. Helaian daun berupa daun majemuk dengan 3 anak daun, masing-masing berbentuk bulat telur, tangkai anak daun pendek, pangkal tangkai anak daun membesar, ujung runcing, pangkal membulat, kedua permukaan helaian daun berambut, ukuran helaian daun 4,5-16 x 2,5-11 cm. Kandungan kimia pada biji mengandung glukoprotein, tripsin inhibitor, hemaglutinin, stigmasterol, sitosterol, kampesterol, alantoin dan inositol. Kulit biji mengandung leukopelargonidin, leukosianidin, leukodelpinidin, kaempferol, kuersetin, mirsetin, pelargonidin, sianidin, delfinidin, petunidin, dan malvidin (BPOM RI, 2010).

Allium cepa merupakan tumbuh berumpun, berumbi lapis, berakar serabut dengan daun berwarna hijau panjang berbentuk silinder yang ujungnya lancip dan berongga. Bunga berwarna putih kemerah-merahan. Umbi bawang merah terbentuk dari pangkal daun yang bersatu dan membentuk batang yang berubah bentuk dan fungsinya, membesar dan akhirnya membentuk umbi berlapis. Umbi berwarna merah keunguan, berbau tajam. Kandungan kimia kuersetin yang 
Helen Anjelina Simanjuntak, Pemanfaatan Tumbuhan Obat Diabetes Mellitus di Masyarakat

merupakan sejenis flavonoid (Bryan et al. 2015).

Aloe vera merupakan herba menahun, $30-50 \mathrm{~cm}$. Batang rebah, panjang 2-3 cm, bercabang di pangkal, membentuk tunas-tunas di setiap buku. Daun lanset tebal dan mengkilap, panjang 40 - $50 \mathrm{~cm}$, lebar 6 - $7 \mathrm{~cm}$ pada bagian dasar daun. Permukaan daun bagian atas konkaf, abu-abu hijau terkadang ujung kemerahan. Tepi daun berwarna merah jambu pucat dan $2 \mathrm{~mm}$ gigi-gigi yang berwarna pucat. Bunga infloresense lurus ke atas dapat mencapai $60-90 \mathrm{~cm}$. Kandungan kimia berupa aloe emodin yang tergolong dalam senyawa antraquinone yang mempunyak kemampuan menurunkan kadar gula darah (Sudjono, 2005).

\section{Bagian Organ Tumbuhan yang Digunakan sebagai Obat Diabetes Mellitus}

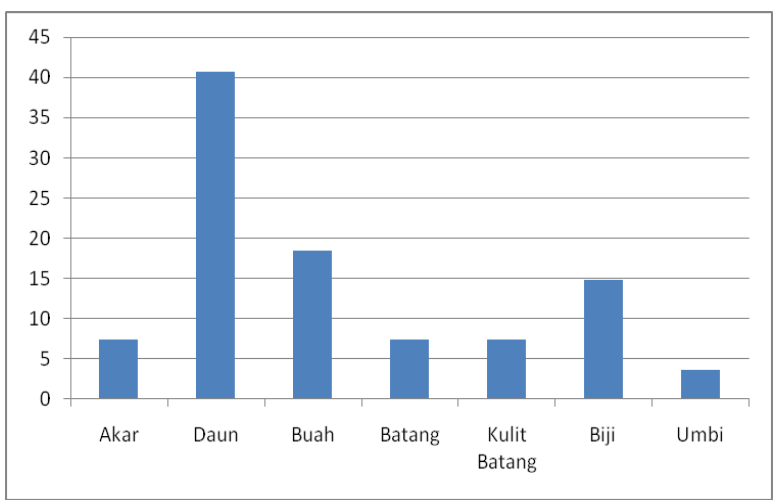

Grafik 1. Bagian Organ Tumbuhan Yang digunakan sebagai Obat Diabetes Mellitus

Dari grafik di atas dapat dilihat bahwa organ tumbuhan yang dominan digunakan dalam pengobatan diabetes mellitus adalah bagian daun sebesar 40,74\%. Daun merupakan bagian tumbuhan yang paling mudah diperoleh dibandingkan dengan bagian-bagian yang lain. Hal ini juga menunjukkan bahwa pemanfaatan tumbuhan oleh Masyarakat Etnis Simalungun masih dilakukan secara lestari. Pada umumnya pengambilan bagian tumbuhan tersebut tidak memberikan dampak yang besar pada pertumbuhan tersebut, sebab daun memiliki regenerasi yang tinggi untuk kembali bertunas dan tidak memberi pengaruh yang besar terhadap pertumbuhan suatu tumbuhan meskipun daun tempat fotosintesis (Fakhrozi, 2009). Handayani (2003), menjelaskan bahwa daun merupakan bagian (organ) tumbuhan yang paling banyak digunakan sebagai obat tradisional karena daun umumnya bertekstur lunak, memiliki kandungan air yang tinggi (70-80\%) dan merupakan tempat akumulasi fotosintat yang diduga mengandung unsur-unsur (zat organik) yang memiliki sifat dapat menyembuhkan penyakit, dan banyak memiliki kandungan seperti minyak atsiri, fenol, senyawa kalium, dan klorofil. Pemanfaatan bagian daun untuk obat lebih mudah cara penglahannya. Selain mempunyai khasiat yang lebih baik dibandingkan bagian-bagian tumbuhan yang lain, penggunaan daun juga tidak 
BioLink, Vol. 5 (1) (2018): hal. 59-71

merusak organ tumbuhan. Hal ini dikarenakan bagian daun mudah tumbuh kembali dan dapat dimanfaatkan secara terus-menerus sampai tumbuhan tersebut tua dan mati (Zuhud \& Haranto, 1994).

\section{SIMPULAN}

Masyarakat Etnis Simalungun memanfaatkan tumbuhan Obat sebagai obat diabetes mellitus yang terdiri dari 20 Famili, 15 Ordo dan 26 Jenis yaitu: Phyllanthus niruri, Ficus septica, Morus alba, Alstonia scholaris, Catharanthus roseus, Strychnos ligustrina, Taraxacum officinale, Momordica charantia, Morinda citrifolia, Strobilanthes crispus, Coleus scutellariioides, Orthosipon stamineus, Physalis minima, Centella asiatica, Averrhoa carambola, Theobroma cacao, Psidium guajava, Syzygium polyanthum, Syzygium cumini, Carica papaya, Persea americana, Cinnamomum burmanni, Tinospora crispa, Phaseolus vulgaris, Allium cepa, Aloe vera. Dan bagian organ tumbuhan yang digunakan adalah bagian akar, daun, buah, batang, kulit batang, biji dan umbi.

\section{DAFTAR PUSTAKA}

Azhari, N.T.P dan Ety. A. (2016). Peranan Jombang (Taraxacum officinale) sebagai Hepatoprotektor. Majority. Volume 5 (5). Desember 2016. Universitas Lampung.

BPOM RI. (2007). Acuan Sediaan Herbal. Volume Ketiga Edisi Pertama. Direktorat Obat Asli Indonesia.
BPOM RI. (2010). Acuan Sediaan Herbal. Volume Kelima Edisi Pertama. Direktorat Obat Asli Indonesia.

BPOM RI. (2013). Formularium Ramuan Etnomedisin Obat Asli Indonesia. Volume Ketiga. Direktorat Obat Asli Indonesia.

Bryan. Y.K., Mona.P.W., dan Christi. M. (2015). Pengaruh Pemberian Ekstrak Umbi Bawang Merah (Allium cepa) Terhadap Kadar Gula Darah Tikus Wistar (Rattus norvegicus) Yang Diinduksi Dengan Aloksan. Jurnal eBiomedik (eBM). Vol 3. No.1, Januari-April 2015.

Dalimartha. S. (2000). Atlas Tumbuhan Obat Indonesia Jilid 2. Trubus Agriwidya. Anggota IKAPI. PT. Pustaka Pembangunan Swadaya Nusantara. Jakarta.

Dinasari. D dan Fifteen. A.F. (2015). Uji Aktivitas Antidiabetes Ekstrak Air Kelopak Bunga Rosella (Hibiscus sabdariffa L) Pada Tikus dengan Metode Induksi Aloksan. Jurnal Farmasi Sains dan Terapan. Volume 2. Nomor 1. Januari 2015.

Fakhrozi. I. (2009). Etnobotani Masyarakat Suku Melayu Tradisional Di Sekitar Taman Nasional Bukit Tigapuluh. Fakultas Kehutanan. Institute Pertanian Bogor.

Gusmailina \& S. Komarayati. (2015). Review: Eksplorasi Potensi Senyawa Organik Kayu Ular (Strychos lucida) Sebagai Sumber Biofarmaka. Pros Sem Nas Masy Biodiv Indon. Volume 1(7), Oktober. Pusat Litbang Hasil Hutan. Badan Litbang Kehutanan. Bogor.

Handayani. L. (2003). Membedah Rahasia Ramuan Madura. Jakarta: Agromedia Pustaka.

Harada, K. Rahayu. M., dan Muzakkir. A. (2006). Tumbuhan Obat Taman Nasional Gunung Halimun. Jawa Barat. Indonesia. PALMedia creative pro. Bandung.

Kim JS, Ju JB, Choi CW, dan Kim SC. 2006. Hypoglycemic and Antihyperlipidemic Effect of Korean Medicinal Plants in Alloxan Induced Diabetic Rats. Am J of Biochemistry and Biotecnology, 2(4).

Simanjuntak, H.A.. (2016). Etnobotani Tumbuhan Obat di Masyarakat Etnis Simalungun Kabupaten Simalungun Provinsi Sumatera Utara, BioLink, Vol. 3 (1), Hal: 75-80

Setiawan. (2007). Distribusi Penggunaan Antidiabetik Oral Di Rumah Sakit. Jurnal 
Helen Anjelina Simanjuntak, Pemanfaatan Tumbuhan Obat Diabetes Mellitus di Masyarakat

Farmasi Indonesia. Universitas Farmasi Purwekerto

Setiawan. A.S., Elin. Y., Ketut. A., Hikmat. P., dan Primal. S. (2011). Efek Antidiabetes Kombinasi Ekstrak Bawang Putih (Allium sativum Linn) dan Rimpang Kunyit (Curcuma domestica Val) dengan Pembanding Glibenklamid pada Penderita Diabetes Melitus Tipe 2. MKB. Volume 43. No.1. Fakultas Kedokteran Gigi. Universitas Padjaddjaran.

Sudjono T.A., Wahyuni. A.S. (2005). Pengaruh Decocta Daun Lidah Buaya (Aloe vera) terhadap Kadar Glukosa Darah Kelinci Yang Dibebani Glukosa. Jurnal Penelitian Sains dan Teknologi.

Sheliya M.A, Rayhana B, Ali A. Pillai KK, Aeri V, Sharma M, Mir SR. (2015). Inhibition of $\alpha$ glucosidase by new prenylated flavonoids from euphorbiahirta L. herb. J Ethnopharmacol.

Yuda. I.K.A., Made. S.A.., Anak. A.G.O. Dharmayudha. (2013). Identifikasi Golongan
Senyawa Kimia Ekstrak Etanol Buah Pare (Momordica charantia) dan Pengaruhnya Terhadap Penurunan Kadar Glukosa Darah Tikus Putih Jantan (Rattus novergicus) yang Diinduksi Aloksan. Buletin Veteriner Udaya. Vl 5.(2). Agustus. Universitas Udayana-Bali.

Zega. V., Pemsi. M.W., Christi. M. (2016). Uji Beberapa Dosis Ekstrak Buah Mengkudu (Morinda citrifolia L) terhadap Kadar Glukosa Darah Pada Tikus Wistar (Rattus norvegicus) yang diinduksi Aloksan. Jurnal e-Biomedik (eBM). Volume 4. Nomor 2.

Zuhud, EAM dan Haryanto. (1994). Pelestarian Pemanfaatan Keanekaragaman Tumbuhan Obat Hutan Tropika Indonesia. Jurusan Konservasi Sumberdaya Hutan Fakultas Kehutanan IPB dan Lembaga Alam Tropika Indonesia (LATIN). Bogor. 